\title{
Household access to agricultural credit and agricultural production in Nigeria: A propensity score matching model
}

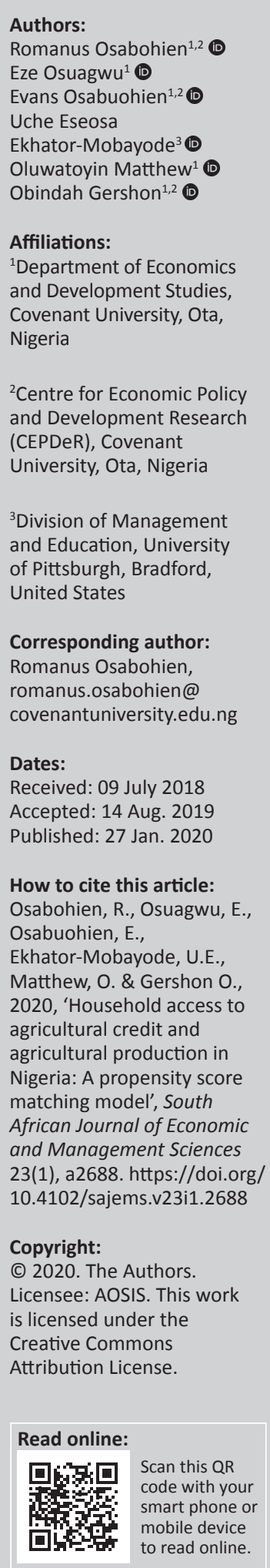

\section{Authors:}

Eze Osuagwu ${ }^{1}$ (D

Evans Osabuohien ${ }^{1,2}$ (D)

Uche Eseosa

khator-Mobayode

Oluwatoyin Matthew ${ }^{1}$

Affiliations:

Covenant University, Ota

${ }^{2}$ Centre for Economic Policy and Development Research (CEPDeR), Covenant

${ }^{3}$ Division of Management and Education, University of Pittsburgh, Bradford,

Corresponding author: Romanus Osabohien, romanus.osabohien@

Dates:

Received: 09 July 2018 Accepted: 14 Aug. 2019

How to cite this article: Osabohien, R., Osuagwu, E. Matthew, O. \& Gershon O 2020, 'Household access to agricultural credit and agricultural production in Nigeria: A propensity score matching model', South and Management Sciences 23(1), a2688. https://doi.org/

\section{Copyright:}

(c) 2020. The Authors. Licensee: AOSIS. This work Creative Commons Attribution License.

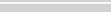

\begin{abstract}
Background: Agricultural production is low in Nigeria as a result of low utilisation of farm inputs facilitated by farmers' inability to save and invest. Therefore, credit is needed by farmers to enhance their productive capacity and efficiency in agriculture.
\end{abstract}

Aim: Given the importance of credit to farmers, this study examined the nexus between households' access to credit and agricultural production in Nigeria.

Setting: The study made use of data from the Living Standard Measurement Study-Integrated Survey on Agriculture (LSMS-ISA) consisting of 4210 households across the 36 states in Nigeria, as well as the Federal Capital Territory, Abuja.

Methods: The study employs the propensity score matching (PSM) technique.

Results: The main result from the study suggests that households who had access to agricultural credit facilities had yields that are thrice those of their counterparts who did not benefit from such facilities. In the event of a shock, the farmers who did not have a source of credit are often forced to adopt measures such as lowering consumption and selling assets, which in the long run worsen their poverty levels.

Conclusion: The study recommends that policymakers should address underlying factors that prevent access to credit for agricultural production, which is capable of raising the productive capacities of farmers.

Keywords: access to credit; agriculture; household; production; propensity score matching.

\section{Introduction}

In developing countries, about 1.5 billion households live in extreme poverty (Food and Agricultural Organisation [FAO] 2016). Approximately 75\% of these individuals who live on less than $\$ 1.25$ reside in rural areas of many sub-Saharan African (SSA) countries, where they depend mainly on agriculture for survival (FAO 2016; Osabohien, Osabuohien \& Urhie 2018). It has been noted that for the past two decades, credit policies have expanded rapidly in most of the developing countries, as 2.1 billion people benefited from social protection policies including social assistance, social insurance and labour market interventions (Croppenstedt, Knowles \& Lowder 2017). Although globally about 35\% of the population receives some form of credit assistance, in rural SSA communities many households do not have access to credit facilities, resulting in low agricultural production, among others (Adjognon, Liverpool-Tasie \& Reardon 2017; FAO 2016; Osabohien et al. 2019).

Consequently, the little income generated by rural farmers from agriculture is frequently insufficient and vulnerable to shocks, such as drought, pests and diseases outbreak, weather variations and death. Without adequate credit assistance, farmers will no doubt suffer hardship and long-term deficiency, because access to credit provides households with emergency relief, such as the purchase of seeds, fertilisers and livestock, among others. Therefore, in the absence of this, farmers are liable to hardship (Croppenstedt et al. 2017; Rehman et al. 2017). It has also been observed that the insufficient telecommunication base alongside weak agricultural investment and human capital development have increased the vulnerability of farmers and contributed to low production (Osabohien, Matthew, Gershon, Ogunbiyi \& Nwosu 2019; Ejemeyovwi, Osabuohien \& Osabohien 2018; Osuma, Ikpefan, Osabohien, Ndigwe \& Nkwodimmah 2018).

In most cases, these poor farmers in rural communities often choose livelihood strategies that forego income to ensure survival, so that when shocks occur, they are often forced to cope in ways 
that increase their vulnerability or undermine their future income generation capacity (Dercon 2011). It has been observed that $40 \%$ of the rural farmers in SSA rely predominantly on agriculture as an occupation for their livelihoods; well-structured local institutions and credit facilities are needed for production enhancement (Osabohien, Afolabi \& Godwin 2018; Osabuohien, Okorie \& Osabohien 2018; World Bank 2008).

Households' access to agricultural credit has been known to be the main input in the development of the agricultural sector (Adjognon et al. 2017). The reduction of the contribution of agriculture to the gross domestic product in Nigeria has been attributed to the insufficient access to agricultural credit (Mallum 2016). The Nigerian government has recognised the importance of agriculture in the economy, which has led to the implementation of various agricultural credit policies to enhance the production capacity of the sector (Mallum 2016). The major agricultural credit policies in Nigeria include the Agricultural Credit Guarantee Scheme Fund (ACGSF), the Agricultural Credit Support Scheme (ACSS) and the Commercial Agriculture Credit Scheme.

In the credit scheme, the government holds $60 \%$ and the Central Bank of Nigeria (CBN) holds the remaining $40 \%$ of the shares. The capital base of the scheme was increased to 3 billion naira in March 2001 with a view to increasing households' access to credit. The ACGSF was extended to the farmers by banks up to $75 \%$ of the amount in default, net any security realised. Between 1978 and 1989, when the government stipulated lending quotas for banks under the scheme, there was a consistent increase in the lending portfolios of banks to agriculture, but after the deregulation of the financial system, commercial banks in Nigeria failed to fulfil the agreement by reducing bank loans to the agricultural sector due to the perceived risk.

On the other hand, the ACSS is a programme that advocated that about 50 billion naira in access funds should be granted to farmers. Also, the ACSS was introduced to enable farmers to take advantage of the unharnessed potential of the Nigerian agricultural sector, reduce inflation, lower the cost of agricultural production (for example, food items), generate surplus for export, increase Nigeria's foreign earnings, as well as diversify its revenue base (CBN 2019; Osabuohien, Obiekwe, Urhie \& Osabohien 2018). To access loans under the ACSS, the applicants (practising farmers and agro-allied entrepreneurs) are encouraged to approach their banks for a loan through the respective State chapters of farmers' associations and state implementation committees. However, large-scale farmers are allowed, under the scheme, to apply directly to the banks in accordance with the guidelines, while small-scale farmers were systematically excluded as a result of the collateral required to access loans. Therefore, the implementation of credit policies in Nigeria is often not the major constraint to credit, rather the failure of donor agencies to ensure timely provision of credit to farmers.
Timely access and credit availability are critical to farmers for acquiring the required inputs and machinery necessary to carry out farm operations. The major problem faced by farmers is limited access to credit facilities, which hinders the adoption of more efficient and modern technologies in the farm operation. This lack of resources not only limits the possibilities of increased productivity, but it also hinders the capacity for smooth consumption (Saqib et al. 2018). Farmers purchase most of their inputs in cash or from dealers on a credit-in-kind basis, leading to increased dependence of farm households on credit markets. An efficient credit market provides farmers with the opportunity to meet consumption requirements and proper input use, thus improving the welfare of the farmers, small-scale agriculturalists, helping them to manage risks more effectively and improve agricultural production, leading to more sustainable livelihoods and progress out of poverty and hunger (Holmes et al. 2011; Matthew et al. 2018; Saqib et al. 2018; Afolayan et al. 2019).

Generally, agricultural credit facilities can be in the form of a loan or overdraft, among others, that is made available for farmers to help boost their productive capacity, which will increase their earnings; this in turn reduces socio-economic risks, vulnerability, poverty and deprivation (Croppenstedt et al. 2017). Credit facilities can be in the form of smallholder agricultural policies, which focus on improving crop production, fisheries, forestry and livestock and improving access to markets (Osabohien et al. 2019; World Bank 2008). Credit policies are required in reducing the incidence of rural poverty through the sale of farm yields. However, farmers have been largely neglected regarding access to credit facilities in the majority of developing countries, especially in Nigeria where the emphasis has been placed instead upon the primacy of economic growth, rather than the agricultural sector which employs more than $75 \%$ of the total labour force in the country (United Nations Conference on Trade and Development [UNCTAD] 2016; World Bank 2007).

Saqib et al. (2018), Adjognon et al. (2017) and Suri et al. (2009) are among the few studies that addressed agricultural credit policies in SSA and provide the framework for agricultural interventions and the livelihood of rural farmers in Kenya and in Nigeria. These studies described the agricultural intervention as providing income through direct seed and cash transfers in order to reduce hunger and poverty, but whether the credit policies were successful or not remains an issue for discourse. However, in the case of Nigeria, there is a dearth of literature that addresses the issues of access to agricultural credit for the rural farmer, which forms the motivation for this study.

Theoretically, there could be a bi-directional association between access to credit and agriculture production (Tirivayi, Knowles \&Davis 2016; Matthew, Ede, Osabohien, Ejemeyovwi, Ayanda \& Okunbor 2018). On the one hand, farmers in rural communities who are poor and depend solely on agriculture for a living are often faced with closed 
access to assets, low agricultural production and recurrent exposure to covariate and peculiar risks (Devereux et al. 2008; Tirivayi et al. 2016). In addition, the consistency and assurance of credit instruments help farmers to better manage risks and engage in more profitable livelihood and agricultural activities.

From the foregoing, this study adds to the existing literature by examining the extent to which households' access to agricultural credit impact on the farmers' agricultural productivity in Nigeria using wave 2 data from the Living Standard Measurement Study-Integrated Survey on Agriculture (LSMS-ISA). The findings from the study showed that households who have access to agricultural credit in the form of cash or in-kind support had yields thrice those of households that did not have access to agricultural credit. Therefore, the study recommends that policymakers should address underlying factors that prevent access to credit for agricultural production, which is capable of raising the productive capacities of the farmers. The remainder of this study is structured as follows: a review of the relevant literature, a discussion of the various underlying theories, an explanation of the methodology, presentation of the empirical results and finally the conclusion of the study.

\section{Insights from the literature}

Ewetan et al. (2017) examined the effect of government expenditure on agricultural production in Nigeria. The study noted that, whether the effect is being looked at from the macroeconomic or microeconomic level, most of the existing literature assumes that government expenditure (credit facility) has a significant impact on agricultural production. The direction of the impact differs from one study to another, with a greater positive effect on average in developing countries. Adjognon et al. (2017) used two-stage sampling techniques with data from the LSMS-ISA for two panel waves: wave $1(2010 / 2011)$ and wave $2(2012 / 2013)$, covering 3000 farming households. They validated the findings of Suri et al. (2009) noting that farmers in SSA often experienced low yields as a result of limited access to agricultural credit facility.

United Nations Conference on Trade and Development (2016) viewed credit facility as a development priority in the post-2015 United Nations (UN) development agenda, which posits that $80 \%$ of the global rural farmers, mainly in Africa, have no access to credit facilities. Credit policies help households to generate income from farming operation that enables them to handle the different aspects of poverty, employment and deprivation (decent work, education, healthcare, food security, income security) and can, therefore, be a powerful tool in tackling poverty and inequality (Adjognon et al. 2017; Chandio et al. 2017; Rehman et al. 2017; Matthew et al. 2019). In addition to the above assertion, United Nations Development Programme (UNDP 2016) posited that credit policies are among the most successful development experiences the world has seen from the 1990s to date. This is because households' access to credit have proven to be relevant tools in developing countries' efforts to fight poverty and hunger, as demonstrated by the substantial progress countries such as Brazil, Tanzania, Ethiopia, Senegal, and Kenya have made in poverty reduction through the adoption and expansion of credit schemes. Credit policies, when efficiently directed towards agriculture, have the potential to contribute significantly to employment generation, poverty reduction and long-term sustainable production, especially when built under a broader, more integrated framework.

Furthermore, Tirivayi, Knowles and Davis (2016) examined the interaction between credit policies and agriculture using a quantitative study and found that little attention has been paid to the interaction between credit access and agricultural production in rural communities, and how they influence the design and the implementation of credit policies to achieve sustainable agriculture outcomes. In line with that, controlling for seed, Njine (2006) compared actual maize and cassava yields from the trial station in Kenya, using different fertiliser combinations, with yields obtained by farmers on site with characteristics similar to the trial stations. The study estimated technical inefficiency of the farmers at $60 \%$, suggesting that effective credit towards agriculture is needed for sustainable agricultural production.

Croppenstedt et al. (2017) examined the impact of agricultural credit facilities on agriculture and pointed out that evidence has shown that economic growth is an important element of poverty reduction. However, in Nigeria and other developing countries with a large proportion of the workforce engaged in agricultural activities, growth generated from agriculture is a more potent element of poverty reduction. Christiaensen, Demery and Kuhl (2011) confirmed the validity of Croppenstedt et al. (2017) by pointing out that economic growth may not be inclusive and poverty reduction following economic growth tends to be slow and does not really benefit farmers in rural communities; they conclude that growth generated from agriculture is more inclusive than growth generated from any other sector of the economy.

Barrett et al. (2006) offered supporting evidence of the potential of credit policies in Madagascar. Barrett et al. also reported that the current spending on agricultural research to enhance the production of crop production in Madagascar is about $2.5 \%$ of the total annual value of crop production. Validating the impact of credit facilities on agricultural production, Chandio et al. (2017), in their study, examined the impact of agricultural credit on production in Pakistan using a cross-sectional random sampling technique of 180 rice producers in the Sindh area of Pakistan. The study employed the maximum likelihood estimate and the result showed that households' access to credit enables them to increase their farm size that significantly impacts on the productive capacity of farmers in the Sindh area of Pakistan. The study concluded that households' access to credit and farm size are the two main factors in improving the level of agricultural production in, as well as the technical efficiency of small-scale farmers in Pakistan. 
Iganiga and Unemhilin (2011) investigated the impact of agriculture credit on the value of agricultural production in Nigeria and found that commercial bank credit is positively related to agricultural production using the Cobb-Douglas production function. In a line study, Osabohien, Afolabi and Godwin (2018) examined the impact of commercial bank credit and the ACGSF on agricultural production towards achieving food security in Nigeria; the study employed secondary data sourced from the world development indicators and the CBN statistical bulletin for the period (1986-2016) and employed the Autoregressive Distribution Lag (ARDL) econometric approach. The study found that access to commercial bank credit increased farm yields by $8.12 \%$ and access to the ACGSF increased farm yields by $0.2 \%$.

These findings from the empirical literature signal the importance of households' access to credit towards increasing the agricultural production in Nigeria. Despite the findings of the effect of access to credit on agricultural productivity across various countries, the adoption of an effective credit policy towards the agricultural sector remains relatively low in Nigeria. At one level, this situation reflects the lack of adequate public funding devoted to agricultural research and its dissemination, especially in the area of crop production. To make a case for public funding towards agricultural credit, the government is advised to use agricultural credit to encourage the farmers to be able to increase agricultural output.

In the light of the foregoing issues reviewed in the literature, it becomes obvious that households' access to credit will invariably improve agricultural production, thereby reducing the rate of poverty among rural dwellers who solely engage in agriculture. Thus, the present study differs from other empirical studies in the field and adds to the literature by probing into the hypothesis of whether households' access to credit has any significant impact on agricultural production in Nigeria, using propensity score matching (PSM) on household data sourced from the LSMS-ISA wave 2 $(2012 / 2010)$. To the best of the knowledge of the authors, the novel idea that the study is contributing to the body of literature, is in the area of credit assistance and agricultural production of farmers in rural communities in Nigeria.

\section{Theoretical framework}

Some theories have emerged on the analysis of poverty and government intervention in the form of credit facilities, but few theories have been confined to the understanding of households' access to credit and agricultural production; especially when it has to do with rural farmers. However, this study has examined in summary: the credit channel theory, the classical and the neoclassical views, the Keynesian and Marxian views, including the social exclusion theory leading to the livelihood portfolio theory proposed by De Neubourg (2009), and the Cobb-Douglas production function.

The credit channel theory posited that the interest charged on credit through banks' capital and other means, particularly when banks' lending is constrained by a capital adequacy requirement, thus reducing the rate of interest on credit, will enhance the ability of people to borrow for different operations including farming (Osabohien et al. 2018). However, lenders will also become more eager to lend during certain periods because of an improvement in their underlying financial condition. From the classical viewpoint, individuals are assumed to work their way out of poverty; hence no form of credit assistance is required for poverty alleviation. Poverty is considered inherent and assumes that one can only escape through hard work. In this case, it is difficult for the state to provide support to cushion the effect of poverty.

However, under the neoclassical expression, poverty is more economic and deprivation occasioned by market imperfections that exclude the poor from credit and lack of a fair share in the distribution of factors or economic resources (Bradshaw 2007). On the other hand, the Keynesians are of the opinion that poverty in a society is driven by the lack of public goods and inequality in the distribution of available resources. To this end, a credit facility should be controlled by the state and the distribution should be even, irrespective of social stratification (Bradshaw 2007). For instance, human capital development such as education and health provisions should be the obligation of government and individuals should be guaranteed the opportunity to harness such rights in equal proportion.

Far from this, the neo-Keynesians also argued that there should be an overall growth in human development to uplift the individual from poverty (De Haas 2010). This can only be achieved through government intervention to reduce the negative influence of macroeconomic factors such as inflation, exchange rate and unemployment on the economic wellbeing of the populace (Osabuohien, Obiekwe, Urhie \& Osabohien, 2018).

A more radical dimension was taken by the Marxian economists espousing that economic growth alone may not possibly lift the poor, especially peasant farmers, out of poverty, because of class struggle in the capitalist system where the factors of production are controlled by the rich (Shildrick \& Rucell 2015). They would rather prefer mainstream economic stability, which includes both economic and environmental improvements, because the poor are most vulnerable to environmental disasters, especially in farming. The social exclusion theorists were the most fundamental in the recognition of structural changes in society. The inadequacy of credit capital was understandably the challenge of this school of thought. Nevertheless, they streamlined the definition of poverty to those unable to receive credit benefits (Bradshaw 2007; De Haas 2010; Shildrick \&Rucell 2015).

In addition, Sen and Dreze (1989) suggested that more attention should be directed to wage and labour market outcomes in the distribution of economic resources, and political considerations should be channelled into an institutional framework for the provision of welfare. As a result, definitions of poverty sprang up from multilateral 
institutions such as the World Bank (2008) - the inadequate physical security and lack of political voice - and the United Nation Programme (2016): lack of participation in decisionmaking and in civil, social and cultural life. This broad concept of poverty encapsulates all the social and economic dimensions of deprivation, for both individual and group significance.

However, the development of the social exclusion theory leads to what De Neubourg (2009) referred to as the livelihood portfolio theory, where institutions - family, markets, social networks, member institutions and public authorities - are believed to be the core driving force of credit policy for the household. Under the livelihood portfolio theory, De Neubourg, using the welfare pentagon, expressed the interaction between credit agents in the determination of household welfare, given certain basic assumptions of utility maximisation and income constraints, occasioned by consumption risks. These consumption risks are mitigated by public authorities through social security benefits and agricultural subsidies for farming communities or individuals relying on family or communal support to compensate for a shock.

\section{Methodology \\ Data}

This study used cross-sectional data sourced from the LSMSISA wave $2(2012 / 2013)$. The LSMA-ISA was conducted by the World Bank in collaboration with the National Bureau of Statistics and applied in Osabohien (2018) and Osabuohien (2014). The dataset from LSMS-ISA covers the 36 states in Nigeria including Abuja the Federal Capital Territory.

The data is classified into three groups: agriculture, households and community for the two periods of the survey (post-planting and post-harvest, Devarajan [2013]). For the purpose of this study, the community-level data is utilised, involving the merging of both the post-planting and postharvest data, as the variable of interest is either of the periods. The post-planting interview was carried out in August 2012 - October 2012, while the post-harvest data was conducted February 2013 - April 2013. The data for the study was integrated at household level where the information needed is available, which covered 4210 households. Description of the variables engaged is presented in Table 1.

\section{Outcome variable}

To determine the outcome variable, households were interviewed about their farm harvest in wave $2(2012 / 2013)$ post-harvest agriculture season in the LSMS-ISA data. Questions regarded the land area of crop harvested, name of crops planted, unit of crops harvested and how many units of crops were sold since the last interview. Households who harvested crops are represented by 1 , while households who did not harvest were represented by 0 . Reasons for not harvesting were ascertained in the survey; such reasons include: lost crop due to drought, lost crop due to flood, lost crop due to pest, lost crop due to violence, lost crop due to theft, disagreement on land ownership, unable to work due
TABLE 1: Description of variables.

\begin{tabular}{|c|c|}
\hline Variable & Description \\
\hline \multicolumn{2}{|c|}{ Outcome variable: } \\
\hline $\begin{array}{l}\text { Agricultural } \\
\text { production }\end{array}$ & $\begin{array}{l}=1 \text { if household harvested crop in the } 12 \text { months preceding the } \\
\text { LSMS-ISA post-harvest interview, }=0 \text { otherwise }\end{array}$ \\
\hline \multicolumn{2}{|c|}{ Control variable/Household characteristics: } \\
\hline Access to credit & $=1$ if a household has access to credit, $=0$ otherwise \\
\hline Education & $=1$ if a household is able to read and write, $=0$ otherwise \\
\hline Household head & $=1$ if household head is male, $=0$ otherwise \\
\hline Capital & $=1$ if household owns farming equipment, $=0$ otherwise \\
\hline Labour & $=1$ if household hires labourers, $=0$ otherwise \\
\hline Land & $=1$ if household owns land, $=0$ otherwise \\
\hline Health & $\begin{array}{l}=1 \text { if household has consulted health practitioners since the last } \\
\text { survey, }=0 \text { otherwise }\end{array}$ \\
\hline Information & $\begin{array}{l}=1 \text { if household has access to information, e.g. radio or } \\
\text { television, }=0 \text { otherwise }\end{array}$ \\
\hline
\end{tabular}

to sickness, no available labour and delayed or deferred harvest. Other control variables were considered as important factors that affect production, including the key variable (access to credit), health, education, labour, capital, land and information, which are presented in the next subsection.

\section{Control variables}

The control variables which are included in the study are noted below.

\section{Credit facilities}

Information regarding households' sources of credit were ascertained, for example: if households borrow money, if collateral is required for loan, time duration (in months) required for repayment of a 10000.00 -naira loan, the interest rate on a 10 000.00-naira loan, how much a household has to reimburse on a 10000.00 -naira loan, months a household has to reimburse on a 50000.00 -naira loan, the interest rate on a 50 000.00-naira loan, much a household has to reimburse on a 50 000.00-naira loan, number of months household has to reimburse on a 100000.00 -naira loan, the interest rate on a 100 000.00-naira loan and how much a household has to reimburse on a 100 000.00-naira loan.

\section{Health}

The health of the members of a household was considered as an important factor for production in the study. The health condition of households was ascertained by asking if members of a particular household have visited or consulted a health practitioner during the past four weeks prior to the survey. A household in which no one has consulted health practitioners was represented by 1 , while households who has not consulted were represented by 0 . Households' reasons for consulting health practitioners include: checkup or other preventive care, prenatal checkup, follow-up appointment, new or acute illness, new injury and so on. Health practitioners consulted include traditional healers, doctors, dentists, nurses, medical assistants, midwives, pharmacists, chemists, traditional birth assistants, spiritualists and patent medical vendors.

\section{Education}

Information about education includes whether members in the household can read and write in the English language 
and if they have attended any school; a household in which someone can, was represented by 1 , while those in which no one can read and write were represented by 0 .

\section{Labour}

Information about farm labour was collected. Households who hire labourers to work in their fields were represented with 1 , and 0 otherwise. The number of hours worked per week by hired labourers and the amount of their payment (naira) was factored in, as well as whether they receive any in-kind payment or allowance for this work.

\section{Capital}

Information about capital was based on whether the household owned or rented the farm equipment used, such as tractors. Households who own farm implement were represented by 1 , and 0 otherwise.

\section{Information}

During the survey, households were interviewed about whether they have access to information, for example, if they have access to a radio or television. Households could have access to their own radio or through a family member, friend, neighbour, umbrella centre, workplace, mobile phone or others. A household who has access to information is represented by 1 , and 0 otherwise.

\section{Model specification}

This study employs the PSM, which is a non-parametric technique used in the estimation of the effect of a treatment on a group of persons or subjects, in this case agricultural credit given to rural farmers, based on a control group or those who did not receive such agricultural credit. The effect of the treatment on the treated group is matched with the control group and the difference in behaviour or outcome of interest is calculated using a binary logit or probit model. The method of PSM has been applied by Jalan and Ravallion (2003) on the impact of piped-borne water for children's health in rural India. Also, by Osabuohien et al. (2019) on female labour outcomes and large-scale investments in Tanzania, and by Hermann et al. (2018) on the assessment of the impact of household participation in biofuel feedstock production on agricultural input expenditures in order to show that participation in a sugarcane out-grower scheme is associated with a larger amount of land under staple food crops and higher purchase of farm inputs compared to a control group in Malawi.

Computing the change in the outcome of interest mathematically is depicted as $Y_{i}^{T=1}$ for the outcome of the households who had access to credit and $Y_{i}^{T=0}$ for the control (households who did not have access to credit). Therefore, the change in the outcome that is attributed to participating in social protection policies is computed as:

$$
\Delta Y=Y_{i}^{T=1}-Y_{i}^{T=0}
$$

[Eqn 1]

The average treatment effect therefore will be:

agrout $=E(\Delta \mid T=1)=E\left(Y_{i}^{T=1)} \mid T=1\right)-E\left(Y_{i}^{T=0} \mid T=0\right)$
$E$ is the mean (or the expected value). This equation attempts to capture the outcome of agricultural production of the households or farmers with agricultural credit, compared to what the households would have experienced without agricultural credit (that is, what their production would have been without agricultural credit).

The household characteristics taken into consideration are: age, location, occupation, income, size (number of individuals in the household or family), household head (if the household is led by a male or a female), education, access to credit, health status, number of assets owned by the household, whether the household owns a plot of land, and whether the household cultivates that land. This method was coined by Rosenbaum and Rubin (1983) by proposing the use of PSM as a suitable technique to develop the unequal non-participant data.

The PSM method of analysis is based on the assumptions of conditional independence and common support. The conditional independence assumption assumes that the potential outcomes for households without agricultural credit are independent of their status of being in this category, given a set of observable covariates ' $X$ ':

$$
\text { i.e } \gamma_{i}^{o} \perp p_{i} \mid \mathrm{X}
$$

After an adjustment has been made for noticeable variations, it can be inferred that the mean of the outcome variable is the same for households both with and without agricultural credit. This condition helped in matching the households without agricultural credit as a control group when measuring the effect of agricultural credit on household production. Thus, equation (3) above may be depicted as follows:

$$
\left(\left[Y_{i}^{1} \mid P=1, X\right]=\left[Y_{i}^{0} p=0, X\right]\right)
$$

Another assumption is the similar support condition, which considered the prospect that for each value of ' $X$ ', there is a direct chance of each household being with or without agricultural credit. A recent application of this method is by Nkhata, Jumbe and Mwabumba (2014). Various matching algorithms are applicable when using the PSM technique. This study used the kernel matching algorithm (KMA), as it is found to be suitable for this study mainly because it avoids random pruning.

The KMA was found to give a more effectual outcome and is more appropriate for handling large, asymmetrically distributed datasets (Baser 2006). The KMA is designed in a way that each household with agriculture credit with ' $i$ ' is matched with other control observations that have weights that are inversely proportional to the households without. The weight is computed as:

$$
\mathrm{Wij}=\frac{H(P i-P j) / h}{\sum_{j=1}^{n}(\mathrm{Pi}-\mathrm{Pj}) / h}
$$

$h$ represents the bandwidth. Households in the community with (and without) agricultural credit are indicated as $i$ and $j$. 
Figure 1 is a graphical representation of the PSM. The righthand side is the participant or the treatment side, while the left-hand side is the non-treatment or non-participant side. The participants are the households who benefited from the programmes (social protection policies), while the nonparticipants are households that did not benefit from social protection policies

\section{Ethical considerations}

This article followed all ethical standards for research without direct contact with human or animal subjects.

\section{Results and discussion}

This section of the study presented the result obtained from the analysis. Figure 2 presents the frequency of households' access to credit across zones in Nigeria. There are six

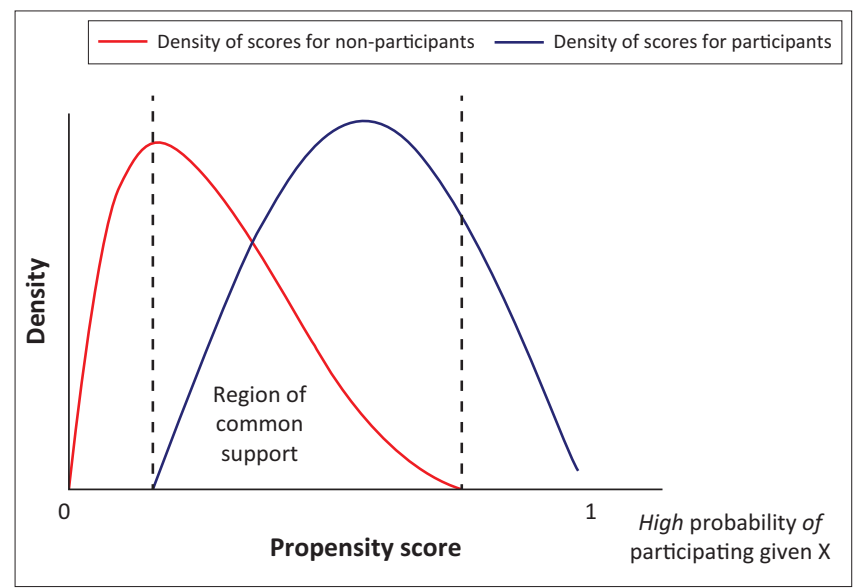

Source: Adapted from CEGA n.d., Matching methods, viewed n.d., from cega.berkeley.edu/ assets/cega_events/31/Matching_Methods.ppt

FIGURE 1: Graphical representation of propensity score matching. geopolitical zones in Nigeria: the north-central, North-East, North-West, South-East, North-West, South-South and South-West. Each of the six geopolitical zones has six states, excluding Abuja, the Federal Capital Territory, making Nigeria a 37-state nation. In line with the findings of Osabohien et al. (2018), Adjognon et al. (2017), Chandio et al. (2017) and Rehman et al. (2017), farmers' low production can be attributed to inaccessibility of credit facilities.

Figure 2 shows that across the six zones in Nigeria, there are far more households who lack access to credit than households who have access to credit. The 'Yes' columns in the figure represent households who have access to credit and ' $N$ ' $^{\prime}$ represents those who have no access to credit. In North-Central (Yes $=135$, No $=662$ ), out of the 979 farming households, 135 households had access to credit (13.79\%), while a larger number of households (662, representing 67.62\%) had no access to credit, thus affirming the reason behind low yields.

In the north-central, 111 households had access to credit $(17.50 \%)$, while 523 had no access to credit (82.49\%). northeast is not different as $88(10.10 \%)$ households had access to credit, as compared to $783(89.90 \%)$ households who had no access to credit. Similarly, in the south-east geopolitical zone, $163(27.35 \%)$ households had access to credit while 579 $(72.65 \%)$ lack access to credit. In south-south and south-west, $130(24.06 \%)$ and 187 (23.97\%) households had access to credit while 618(82.62\%) and 187 (76.03\%) households lack access to credit. This result signals the importance of credit to farming households to enhance production.

\section{Result from kernel density plot}

The kernel density plot approximated the density function of the outcome (agricultural production) variable and

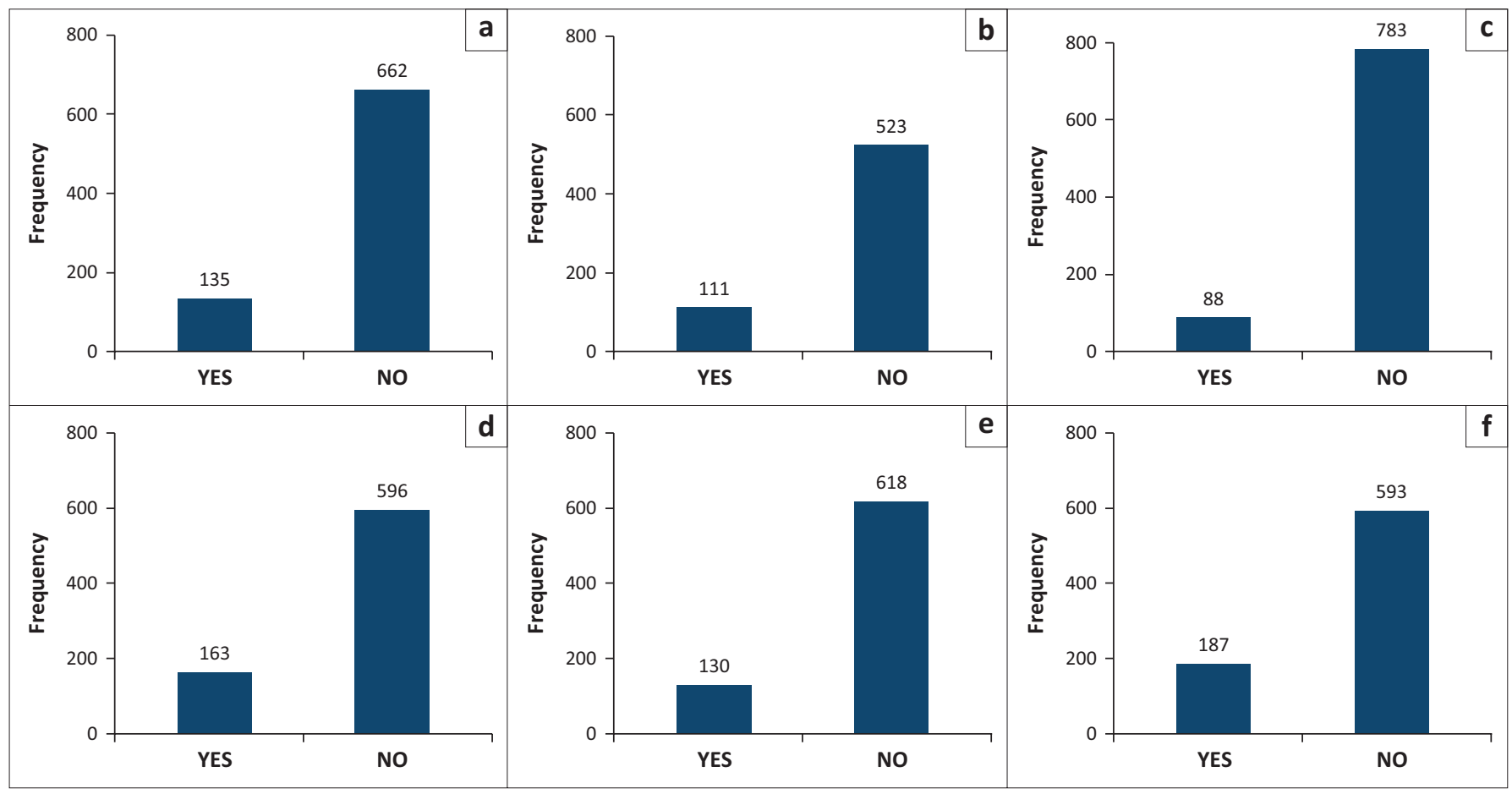

FIGURE 2: Households access to credit by zones in Nigeria: (a) north-central; (b) north-east; (c) north-west; (d) south-east; (e) south-south; (f) south-west. 
compared its trend as shown in Figure 3. The kernel density plot of households' agricultural labour allocation is shown in Figure 3. The results depicted households with agricultural credit being more productive than households without agricultural credit (households without social protection policies).

\section{Household characteristics of propensity score matching}

The household characteristics of interest as mentioned above include size, average age, educational attainment, credit access and land ownership. The descriptive statistics are presented in Table 2, which compares the sample characteristics of households with and without agricultural credit. The aforementioned household characteristics are important as they determine how effective households become in terms of productivity.

\section{The probit model for propensity score matching}

To design a set of variables that can match household characteristics in communities with and without agricultural credit, the probit regression model was applied. The main goal for estimating the probit regression model is to balance the differences in the observable characteristics that may be occurring between the groups (that is, those households who had access to agricultural credit and those households who had no access to agricultural credit). Table 2 shows the result from the probit model, which was used to derive the propensity matching scores. For all households, information, health status, property and labour, whether or not a household is cultivating land or owns and cultivates farm plots are found to be significantly associated with agricultural credit (Herrmann et al. 2018).

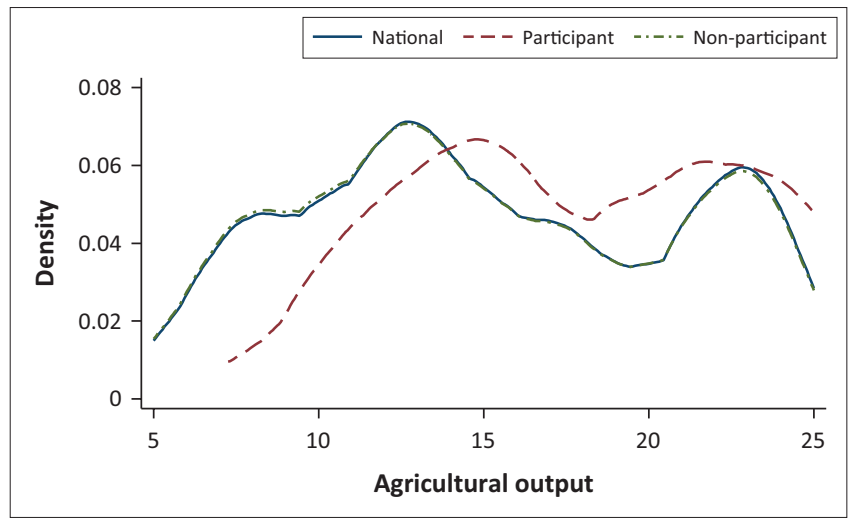

FIGURE 3: Kernel density plot of agricultural credit.
Figure 4 presents the result of the balancing quality checks and the histograms of the predicted propensity scores for both the treated and control groups. From Figure 4, it could be inferred that the propensity score is of equal distribution, suggesting comparability of the treatment and control groups.

\section{Discussion and implication of findings}

The study found that households' access to credit had a positive impact on agricultural production; this indicates that a unit increase in the effectiveness of access to credit facilities will lead to more than a unit increase in agricultural production. Similarly, health status and agricultural production showed a positive relationship that implies that an increase in health status leads to an increase in agricultural production. Labour and agricultural production also showed a positive relationship, which means an increased supply of labour, increased the level of agricultural production. The PSM and the kernel density plot indicated that households who had access to agricultural credit had yields thrice those of their counterparts who did not benefit from such credit. This validated the need for households' effective access to credit in order to increase agricultural production. On the other hand, households who did not benefit from credit facilities are compelled to meet the shortfall in their production and living standard by selling their assets.

From the results in Table 2, we observed that health status, quality of information obtained, availability of land and labour are factors that significantly account for the differences between households with agricultural credit and households without agricultural credit. However, this distinction only drew from the sample characteristics, with less emphasis on

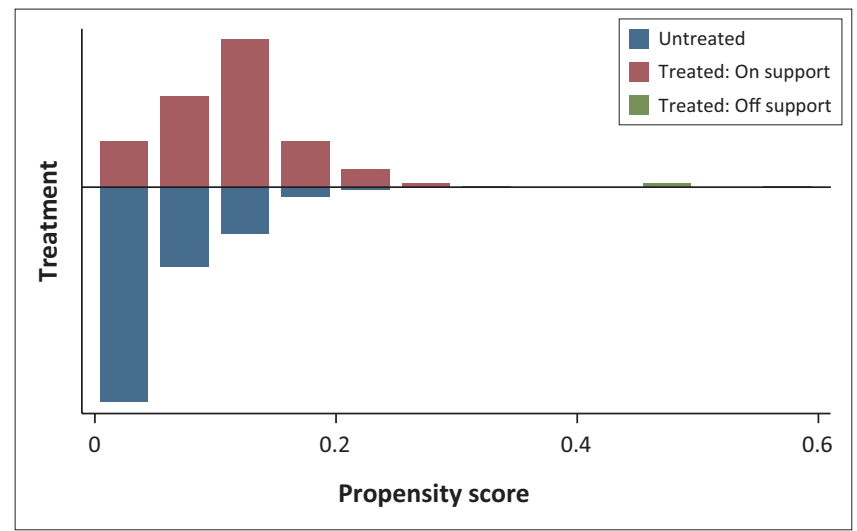

FIGURE 4: Propensity score distribution.

TABLE 2: Comparing household characteristics of propensity score match (Outcome variable: agricultural production).

\begin{tabular}{|c|c|c|c|c|c|}
\hline \multirow{2}{*}{$\begin{array}{l}\text { Agricultural credit } \\
(\text { with }=1, \text { without }=0)\end{array}$} & \multicolumn{2}{|c|}{ Households with agricultural credit } & \multicolumn{2}{|c|}{ Households without agricultural credit } & \multirow[t]{2}{*}{$t$-stat } \\
\hline & Mean & SD & Mean & SD & \\
\hline Health status & 1.8075 & 0.6140 & 1.7892 & 0.4310 & $-4.31 \dagger$ \\
\hline Information & 0.5472 & 0.2944 & 0.5574 & 0.2180 & $4.80 \dagger$ \\
\hline Capital & 1.9872 & 0.0734 & 1.9765 & 0.1221 & -0.99 \\
\hline Land & 0.0100 & 0.0672 & 0.0046 & 0.0370 & $-1.82 \S$ \\
\hline Labour & 1.8212 & 2.2317 & 1.1750 & 1.9819 & $-3.62 \ddagger$ \\
\hline
\end{tabular}

$\mathrm{SD}$, standard deviation.

$\dagger$, and $¥, \S$ indicate levels of significance at $1 \%, 5 \%$ and $10 \%$, respectively. 
the outcome of the experiment. However, the results in Table 3 revealed that information and household labour significantly determined whether the household received any form of agricultural credit or not.

Information asymmetry is an issue of concern, because of the lack of database; information flow is inadequate, so only the privileged in the society would have access to government credit policies. On the other hand, more labour will be put to work if there is a significant incentive for return on labour productivity. In a similar study for Tanzania, Hermann et al. (2018) found that for all households' information, health status, property, labour and whether or not a household owned and cultivated farm plots, are found to be significantly associated with agricultural credit. It is obvious that agricultural credit will improve household health and labour productivity because with extra funds they can purchase better farming tools and good nutrition for an improved standard of living.

The findings of this study are in tandem with the results of Adjognon et al. (2017) on the impact of credit on agricultural production in SSA. The study of Adjognon et al. examined the impact of agricultural input credit on agricultural production in SSA. The study engaged four SSA countries (Mali, Nigeria and Tanzania and Uganda) with 3219 (Mali), 3000 (Nigeria), 3047 (Tanzania) and 2910 (Uganda) farm households using the LSMS-ISA using a two-sample technique. The study found that in Mali $60 \%$ of households has access to a fertiliser subsidy, unlike Nigeria where only $5 \%$ of the fertiliser used by households was subsidised, thus limiting farm yields. However, findings in this study disagreed with Ewetan et al. (2017) who pointed out that agricultural production is the major driver of economic growth using the co-integration approach to examine the long-run relationship between agricultural production and economic growth in Nigeria. Nevertheless, the non-conformity with Ewetan et al. relates to the relationship between agricultural production, economic growth and development.

In the case of Ewetan et al. (2017), the study was taken at the aggregate level without considering how the production capacity of rural farmers could be enhanced. To this end, the aggregate agricultural production that is a requisite in spurring economic growth and development without the inclusion of farmers in rural communities tends to be increasingly ineffectual. This study also agreed with Osabuohien et al. (2019) on the female-labour outcome and

TABLE 3: Probit model for computing the propensity score.

\begin{tabular}{lcc}
\hline Household characteristic & Outcome & Probability values \\
\hline Information & $0.0917^{*}$ & 0.046 \\
Household capital & 0.74170 & 0.153 \\
Health status & -0.4005 & 0.131 \\
Household land & 0.6040 & 0.565 \\
Household labour & $0.0446^{*}$ & 0.018 \\
Constant & $-2.7876^{*}$ & 0.010 \\
Pseudo $R^{2}$ & 0.014 & - \\
Pro value & 0.002 & - \\
Log Likelihood & -437.1680 & - \\
\hline
\end{tabular}

$*, p<0.05$. large-scale agricultural investment in Tanzania, using PSM. The findings revealed that women with investment credit tend to be more productive than women without investment credit. The PSM technique tends to be a more realistic measure of the changes in the behaviour of subjects in a treatment design, where pre-treatment and post-treatment analysis is of the essence.

\section{Summary and conclusion}

This study examined the relationship between households' access to agricultural credit and agricultural production in Nigeria with a view to providing new insights on how the provision of agricultural credit can contribute to increasing agricultural production. The variables include the number of crops produced by household members (farmers in rural communities in which the survey was conducted) measured in percentiles as the outcome variable which captures agricultural production; the major dependent variable is agricultural credit, while other control variables included are agricultural inputs as captured by labour and capital. Labour measures the number of hours farmers work on their farmlands, while capital measures the number of hours or weeks machines were put to work on the farmlands. Similarly, in relation to health as revealed by literature, healthy farmers are no doubt more productive than farmers who are health challenged. Therefore, households' access to agricultural credit or subsidy improves the productive capacity of farmers and those who have no access to credit facilities fall back on the conversion of existing assets to cash to improve their livelihood thereby deepening their poverty.

In conclusion, it is widely believed that agriculture holds the future of the Nigerian economy because it generates employment and income for rural dwellers. The agricultural sector cannot operate in isolation but will perform more efficiently when appropriate credit policies are geared towards empowering those who engage in it. In the light of the above, the study recommended that the agricultural sector should be made more attractive through the implementation and execution of effective credit policies that can help pull labour out from other sectors (labour poaching), as this will enhance the productive capacity of the sector.

As revealed in the study by PSM, households who benefited from agricultural credit had yields thrice those of households who did not have access to credit; this scenario calls for government and donor agencies to effectively implement credit policies in the agricultural sector which will improve the living standards of farmers in rural communities. Therefore, this study has contributed to knowledge by evaluating the impact of households' access to credit facilities on agricultural production in Nigeria using PSM, which to the authors' best knowledge has not been examined in the Nigerian context.

Further studies in this area could be conducted to ascertain the performance of the agricultural sector with respect to human capital development because as households begin to 
receive improved health care facilities and education in new farming techniques and subsidies from the government, there is a tendency for agricultural production to increase. However, a drawback for the implementation of credit policies in a developing country like Nigeria is the lack of an adequate database (identification) for the purpose of disbursement of credit incentives.

\section{Acknowledgements}

This article draws from the thesis of the first author which was presented and submitted to the Department of Economics and Development Studies, Covenant University, Ota, Nigeria. Also, a version of the paper presented was at the 4 th Covenant University International Conference on E-Governance in Nigeria (CUCEN), Covenant University, Ota, Nigeria, held between 07 and 09 May 2017. The comments at the postgraduate seminars and CUCEN participants are appreciated. In addition, the support from Covenant University Centre for Research, Innovation and Discovery (CUCRID) during the preparation of this manuscript is acknowledged.

\section{Competing interests}

The authors have declared that no competing interest exist.

\section{Authors' contributions}

R.O. made contributions in the areas of conception, data collection and analysis. Eze O. did a critical review of the initial draft, ensured that the appropriate methodological approach was followed, and gave the direction for the work. Evans O. and U.E.E.-M. provided guidance on how to use the PSM method and the data from the LSMS-ISA, drawing from their previous research experience, as well as guidance in the discussion of the results. O.M. contributed to the literature aspect of the study and O.G. assisted with formatting and referencing, ensuring that all cited studies are referenced. All the authors read through the various versions of the work and approved the version submitted for publication.

\section{Funding information}

Funding was received from the Covenant University Centre for Research, Innovation and Discovery (CUCRID).

\section{Data availability statement}

Data sharing is not applicable to this article as no new data were created or analysed in this study.

\section{Disclaimer}

The views and opinions expressed in this article are those of the authors and do not necessarily reflect the official policy or position of any affiliated agency of the authors.

\section{References}

Adjognon, S.G., Liverpool-Tasie, L.S. \& Reardon, T.A., 2017, 'Agricultural input credit in sub-Saharan Africa: Telling Myths from Facts', Food Policy 67, 93-105. https://doi. org/10.1016/j.foodpol.2016.09.014
Afolayan, O.T., Okodua, H., Matthew, O. and Osabohien, R. 2019, 'Reducing unemployment malaise in Nigeria: The role of electricity consumption and human capital', International Journal of Energy Economics and Policy 9(4), 63-73.

Barrett, C.B., Marenya, P.P., McPeak, J., Minten, B., Murithi, F., Oluoch-Kosura, W. et al., 2006, 'Welfare dynamics in rural Kenya and Madagascar', The Journal of DevelopmentStudies 42(2), 248-277. https://doi.org/10.1080/00220380500405394

Baser, O., 2006, 'Too much ado about propensity score models? Comparing methods of propensity score matching', The Value in Health 9(6), 377-385. https://doi. org/10.1111/j.1524-4733.2006.00130.x

Bradshaw, T.K., 2007, 'Theories of poverty and anti-poverty programs in community development', Community Development 38(1), 7-25. https://doi.org/10.1080/ 15575330709490182

CEGA, n.d., Matching methods, viewed n.d., from cega.berkeley.edu/assets/cega events/31/Matching_Methods.ppt

Central Bank of Nigeria (CBN), 2019, Delivering price and financial system stability and promoting sustainable economic development, viewed 25 May 2019, from https://www.cbn.gov.ng/AboutCBN/.

Chandio, A.A., Jiang, Y., Gessesse, A.T. \& Dunya, R., 2017, 'The nexus of agricultural credit, farm size and technical efficiency in Sindh, Pakistan: A stochastic frontier approach', Journal of the Saudi Society of Agricultural Science 18(3), 348-354. https://doi.org/10.1016/j.jssas.2017.11.001

Christiaensen, L., Demery, L. \& Kuhl, J., 2011, 'The (evolving) role of agriculture in poverty reduction: An empirical perspective', Journal of Development Economics 96(2), 239-254. https://doi.org/10.1016/j.jdeveco.2010.10.006

Croppenstedt, A., Knowles, M. \& Lowder, S.K., 2017, 'Social protection and agriculture: Introduction to the special issue',Global Food Security 16, 65-68. https://doi. org/10.1016/j.gfs.2017.09.006

De Haas, H., 2010, 'Migration and development: A theoretical perspective', International Migration Review 44(1), 227-264. https://doi.org/10.1111/j.1747-7379.2009.00804.x

Devarajan, S., 2013, 'Africa's statistical tragedy', Review of Income and Wealth 59(Suppl. S1), S9-S15. https://doi.org/10.1111/roiw.12013

Davies, S. \& Davey, J., 2008, 'A regional multiplier approach to estimating the impact of cash transfers on the market: The case of cash transfers in rural Malawi', Development Policy Review 26(1), 91-111. https://doi.org/10.1111/j.1467-7679.2008.00400.x

Dercon, S., 2011, Social protection, efficiency, and growth, CSAE Working Paper WPS/2011 17. Centre for the Study of African Economies, University of Oxford, Oxford.

Devereux, S., Al-Hassan, R., Dorward, A., Guenther, B., Poulton, C. \& Sabates Wheeler R., 2008, Linking social protection and support to small farmer development paper commissioned by the Food and Agricultural Organization of the United Nations, FAO, Rome.

Ejemeyovwi, J.O., Osabuohien, E.S. \& Osabohien, R., 2018, 'ICT investments, human capital development and institutions in ECOWAS', International Journal of Economics and Business Research 15(4), 463-474. https://doi.org/10.1504/ IJEBR.2018.10012862

Ewetan, O., Fakile, A., Urhie, E. \& Oduntan, E., 2017, 'Agricultural production and economic growth in Nigeria', Journal of African Research in Business and Technology 2017, Art. \#516093, 11 pages. https://doi.org/10.5171/2017.516093

Food and Agriculture Organisation, 2016, Agriculture and social protection: Strengthening coordination between social protection, agriculture, and rural Strengthening coordination between social protection, agriculture, and rural
development, viewed 04 August 2017, from http://file://C:/User/Downloads/ development, viewed 04
Social/\%20protection.pdf.

Herrmann, R., Jumbe, C., Bruentrup, M. \& Osabuohien, E., 2018, 'Competition between biofuel feedstock and food production: Empirical evidence from sugarcane outgrower settings in Malawi', Biomass and Bioenergy 114(July), 100-111.

Holmes, R., Akinrimisi, B., Morgan, J. \& Buck, R., 2011, Social protection in Nigeria: An overview of programmes and their effectiveness, project briefing no. 59, UNICEF, New York.

Iganiga, B.O. \&Unemhilin, D.O., 2011, 'The impact of Federal Government agricultura expenditure on agricultural production in Nigeria', Journal of Economics 2(2), 81-88. https://doi.org/10.1080/09765239.2011.11884939

Jalan, J. \& Ravaillion, M., 2003, 'Estimating the benefit incidence of an antipoverty program by propensity score matching', Journal of Business \& Economic Statistics, American Statistical Association 21(1), 19-30. https://doi.org/10.1198/073500102288618720

Mallum, A., 2016, 'A review of agricultural finance policy development in Nigeria', Annals of Borno 26, 167-176.

Matthew, O., Osabohien, R., Fagbeminiyi, F. \& Fasina, A., 2018, 'Greenhouse gas emissions and health outcomes in Nigeria: Empirical insight from ARDL technique', International Journal of Energy Economics and Policy 8(3), 43-50.

Matthew, O.A., Ede, C., Osabohien, R., Ejemeyovwi, J., Ayanda, B. \& Okunbor, J., 2018, 'The interaction effect of tourism and foreign exchange earnings on economic growth in Nigeria', Global Business Review December, 1-16.

Matthew, O.A., Miebaka-Ogan, T., Popoola, O., Olawande, T., Osabohien, R., Urhie, E., Adediran, O. \& Ogunbiyi, T., 2019, "Electricity consumption, government expenditure and sustainable development in Nigeria: A co-integration approach', International Journal of Energy Economics and Policy 9(4), 74-80.

Nkhata, R., Jumbe, C. \& Mwabumba, M., 2014, Does irrigation have an impact on food security and poverty?, working paper no. 25, International Food Policy Research Institute, Washington, DC.

Njine, M.W., 2010, 'Social and economic factors hindering adoption of improved cassava varieties in Kiganjo location, Nyeri municipality division, Kenya', Journal of Developments in Sustainable Agriculture 5(2), 178-190.

Osabohien, R., 2018, 'Contributing to agricultural mix: Analysis of the living standard measurement study-Integrated survey on agriculture data set', Data in Brief 20, 96-100. 
Osabohien, R., Afolabi, A. \& Godwin, A., 2018, 'An econometric analysis of food security and agricultural credit facilities in Nigeria', The Open Agriculture Journal security and agricultural credit facilities in Nigeria', The Open
12, 227-239. https://doi.org/10.2174/1874331501812010227

Osabohien, R., Matthew, O., Gershon, O., Ogunbiyi, T. \& Nwosu, E., 2019, 'Agriculture development, employment generation and poverty reduction in West Africa', The Open Agriculture Journal 13, 82-89.

Osabohien, R., Matthew, O., Aderounmu, B. \& Olawande, T., 2019, 'Greenhouse gas emissions and crop production in West Africa: Examining the mitigating potential of social protection', International Journal of Energy Economics and Policy 9(1), 57-66.

Osabohien, R., Osabuohien, E. \& Urhie, E., 2018, 'Food security, institutional framework, and technology: Examining the nexus in Nigeria using ARDL approach', Current Nutrition and Food Science 14(2), 154-163. https://doi.org/10.2174/1573 401313666170525133853

Osabuohien, E., 2014, 'Land-scale agricultural land investment and local institution: The case of Nigeria', Journal of Land Use Policy 39, 155-165. https://doi. org/10.1016/j.landusepol.2014.02.019

Osabuohien, E., Obiekwe, E., Urhie, E. \& Osabohien, R., 2018, 'The inflation rate, exchange rate volatility and exchange rate pass-through nexus: The Nigerian experience', Journal of Applied Economic Sciences 2(56), 574-585.

Osabuohien, E., Okorie, U. \& Osabohien, R., 2018, 'Rice production and processing in Ogun State, Nigeria: Qualitative insights from Farmers' Association', in E. Obayelu (eds), Food systems sustainability and environmental policies in modern economics, pp. 188-215, IGI Global, Hershey, PA.

Osabuohien, E., Efobi U.R., Herrmann R. \& Gitau, C.M., 2019, 'Female labour outcomes and large-scale agricultural land investments: Macro-Micro evidence from Tanzania', Land Use Policy 82, 716-728. https://doi.org/10.1016/j.landusepol.2019.01.005

Osuma, G., Ikpefan A., Osabohien, R., Ndigwe, C. \& Nkwodimmah, P., 2018, 'Working capital management and bank performance: Empirical research often deposit money banks in Nigeria', Banks and Bank Systems 13(2), 49-61. https://doi. org/10.21511/bbs.13(2).2018.05
Rehman, A., Chandio, A.A., Hussain, I. \& Jingdong, L., 2017, 'Is credit the devil in agriculture? The role of credit in Pakistan's agricultural sector', Journal of Finance and Data Science 3, 38-44. https://doi.org/10.1016/j.jfds.2017.07.001

Rosenbaum, P.R. \& Rubin, D.B., 1983, 'The central role of the propensity score in observational studies for causal effects', Biometrika 70(1), 41-55. https://doi. org/10.1093/biomet/70.1.41

Saqib, S.E., Kuwornu, J.K., Panezia, S. \& Ali, U., 2018, 'Factors determining subsistence farmers' access to agricultural credit in flood-prone areas of Pakistan', Kasetsart Journal of Social Sciences 39(2), 262-268.

Sen, A. \& Drèze, J., 1989, Hunger and public action, Clarendon Press, Oxford.

Shildrick, T. \& Rucell, J., 2015, Sociological perspectives on poverty, Joseph Rowntree Foundation, York.

Suri, T., Tschirley, D., Irungu, C., Gitau, R. \& Kariuki, D., 2009, Rural incomes, inequality and poverty dynamics in Kenya, Tegemeo Institute of Agricultural Policy and Development, Egerton University, Naguru, Kenya.

Tirivayi, N., Knowles, M. \& Davis, B., 2016, 'The interaction between social protection and agriculture: A review of the evidence', Global Food Security 10, 52-62. https://doi.org/10.1016/j.gfs.2016.08.004

United Nations Conference on Trade and Development, 2016, Social protection: A development priority in the post-2015 UN Development Agenda, UNCTAD, Geneva.

United Nations Development Programme, 2016, Social protection for sustainable development: Dialogues between Africa and Brazil, UNDP World Centre for Sustainable Development (RIO+ Centre), Rio de Janeiro.

World Bank, 2007, Down to earth: Agriculture and poverty reduction in Africa, World Bank, Washington, DC

World Bank, 2008, World development report: Agriculture for development, World Bank Group, Washington, DC. 